IIUC STUDIES

ISSN 1813-7733

Vol.- 7, December 2010

(Published in December 2011) (p 249-282)

\title{
Practices of Corporate Social Responsibility: A Study on some Islamic Organizations in Bangladesh
}

\author{
Md. Shariful Haque* \\ Md. Mokhter Ahmad**
}

\begin{abstract}
Corporate Social Responsibility (CSR) is a commitment of the organizations to act ethically and contribute to economic development of the society while humanizing the quality of life of the workforce and the local community at large. This is a talented issue for the corporation the world over. CSR is required for the organizations to ensure its sustainability. Now-a-days the practice of CSR is subject to much debate and criticism. Critics argue that CSR deviates from the fundamental economic role of business; others argue that it is nothing more than superficial windowdressing; others yet argue that it is an attempt to pre-empt the role of governments as a watchdog over powerful multinational corporations. Notwithstanding, CSR is a global concern and all organizations practice it to some extent. In this article the authors made an effort to justify CSR and the concomitant issues in the light of Shariah, and examine the welfare practices of some Islamic Organizations in Bangladesh to see whether those fall under the traditional concept of CSR. An investigation has been made into some Islamic organizations in Bangladesh using an unstructured questionnaire. It transpires from the study that almost all these investigated Islamic organizations practice social responsibilities in different forms like Qard-E-Hasanah, scholarships/stipends, plantation, health services, establishing schools etc.
\end{abstract}

Key words: Social Responsibility, Sustainability, Islamic Organizations, Window-dressing

\section{Introduction}

\subsection{Prelude:}

Corporations do business and business is not separated from the society next to it. The two are interdependent and it must be assured

\footnotetext{
* Assistant Professor, Department of Business Administration, IIUC, Dhaka Campus.

** Associate Professor, Center for University Requirement Courses (CENURC) IIUC, Dhaka Campus.
} 
through mutual empathizing and responsible behavior. Business's role in building a better future is recognized and encouraged by society which may ultimately lead the corporations to the sustainability. And, if it is viewed in the eye of Islam, it may lead the responsible businessman to the success or goodness in hereafter.

Bangladesh is one of the Muslim majority countries. The majority (above $80 \%$ ) of the people of this country are mostly devoted to Islamic way of life as directed in the Qur'an and Hadith. So naturally a deep weep remains in the heart of these people to lead their life in the fashion recommended by Islam (Abdullah, 2008).

In Bangladesh CSR concepts and practices have been seen for a long time. The activities include donations to different charitable organizations, poor people and religious institutions. One can easily notice that most of the businesses in Bangladesh are family owned and first generation businesses. They are involved in community development work in the form of charity without having any definite policy regarding the expenses or any concrete motive regarding financial gains in many instances. Moreover, most of the SMEs (Small and Medium Scale Enterprises) fall under the informal sector where there are low management structure and resources to address the social and environmental issues. These limitations drive the top management of local companies to think only about the profit maximization rather than doing business.

Being a part of the global market, it is difficult to ignore CSR standard specifically in the export sector of Bangladesh. Generally, it is the fact that the condition of labor rights, environmental management and transparency in corporate governance are not much satisfactory in Bangladesh due to 'poor enforcement of existing laws and inadequate pressure from civil society and interest groups like Consumer Forums'. Globally, as CSR practices have been gradually becoming part and parcel of international business practices as well as one of the crucial factors for market accesses, it is becoming equally instrumental for local acceptability. A focus on CSR in Bangladesh is useful, not only for improving corporate governance, labor rights, work place safety, fair treatment of workers, community development and environment management, but also for industrialization and global market access (Mondol, 2009). 
In this article the authors have worked on Islamic Organizations. It is becasue the Islamic Organizations, especially the financial ones, are growing rapidly in Bangladesh in number and network. As all organizations in Bangladesh, especially the financial organizations, are under legal and moral obligations to practice CSR, the Islamic Organizations are more to do so as they work in the name of Islam. Thus a true assessment is the need of the hour to see whether these Islamic Organizations are living up to their legal, moral and religious obligation to practice CSR and/or whether their well-fare practices fall under the definition of CSR. It is to be noted that Islamic Organizations can be defined as those organizations which follow the guidelines of Islamic Shariah in each and every aspect of their functions. As no work has been done, previously, on the CSR activities of Islamic Organization, the authors set their minds to explore what exactly are the contributions of Islamic organizations in the name of CSR.

\subsection{Objectives of the Study:}

The study attempts to focus on the theories and practices of Corporate Social Responsibility particularly by the Shariah based organizations in Bangladesh. So the efforts are engaged aiming to achieve the following objectives:

a. To highlight the context of CSR in Bangladesh

b. To discuss the Practices of CSR by the Shariah Based Organizations viz. Islamic Organizations in Bangladesh

c. To provide some recommendation to encourage the awareness (in taking the necessary measures) to study and practice the CSR from Islamic perspective and implement it for the ultimate sustainable development in the Islamic organizations, in particular, and other organization, in general.

\subsection{Methodology of the Study:}

Major portion of this study is confined to the secondary sources of information like published annual reports and other documents containing information regarding CSR; and relevant documents from the Internet. Using Search Engine the addresses of the websites including the information about the relevant issues have been collected and afterwards information from different pages have been organized and written according to their relevance with the topic. An empirical study has also been conducted using structured questionnaire (5-point Likert Scale). Face to face interview has been taken to fill up the questionnaire. The size of the representative firm is 10 from different 
Islamic Organizations 30. Respondents who are the executives in the managerial level and are particularly responsible to look after the CSR affairs in the respective organizations have been interviewed. Among the organizations the authors have worked on 6 Islamic Banks (Islami Bank Bangladesh Limited, Al-Arafah Islami Bank Limited, EXIM Bank Limited, Shahjalal Islami Bank Limited, Social Islami Bank Limited, and First Security Islami Bank Ltd.), 2 pharmaceutical companies (Ibn Sina Trust and Biopharma Laboratories Ltd.) , 1 Cooperative (Reliance Cooperative Society) and 1 company (KEARI) working in Real Estate and Entertainment services. Data have been processed using the SPSS.

\section{Findings and Analysis:}

2.0 CSR and its conceptualization in the Shariah of Islam:

As this study is solely based on the CSR practices of some Islamic Organizations in Bangladesh, and as majority of her populace as well as the majority of the working forces in her Islamic Organizations are Muslims, the perception of these people about CSR from the perspective of Islamic Shariah is needed to be understood. When contacted, most of them said that their practices of CSR are somehow or other stemmed from and motivated by the understanding of their religious and ethical obligation to the societies. Still many of them were found to have a murky and/or incomplete grasp of CSR and almost all are unaware of the broad dimensions of CSR in the Shariah of Islam.

Social Responsibility refers to the obligations that an organization has to protect and contribute to the society in which it functions' (Barney and Griffin 1992). The concept of CSR is the outcome of the contents and contexts of the study by management gurus over the last half a century. Sometimes it has been denied, sometimes it has been confirmed on ethical grounds while some other times it has been given such a guise which is just a camouflage for making much more profit. In Islam, CSR is not an option, rather an obligation. Because, Islam declares that whatever leads to the welfare of the individuals or the society is morally good and whatever is injurious to either is morally bad. While depicting the definition of righteousness in the Qur'an, Allah (SWT) incorporated different aspects of social responsibilities, indeed representatively, under its purview:

It is not righteousness that you turn your faces towards East or West; but it is righteousness- to believe in 
Allah and the last Day and the Angels, and the Book, and the Messengers; to spend of your substance, out of love for Him, for your kin for orphans, for the needy, for the wayfarer, for those who ask; and for the freeing of captives; to be steadfast in prayer, and practice regular charity; to fulfill the contracts which you made; and to be firm and patient in pain (or suffering) and adversity and throughout all periods of panic, such are the people of truth, the God-conscious (2:177).

In this verse of the Holy Qur'an some comprehensive characteristics of social responsibility have been reflected. In other verses, those who deny their social responsibilities are abhorred by the divine commandments. The following one is typical of many of such Qur'anic testimony:

Have you seen him who calls the judgment a lie? (1) That is the one who treats the orphan with harshness, (2) And does not urge (others) to feed the poor (3) So woe to the praying ones (4) Who are unmindful of their prayers, (5) Who do (good) to be seen, (6) And withhold the necessaries of life (7) (107:1-7).

The Prophet once asked his Companions, "Do you know who the bankrupt is?" The Companions said, "A bankrupt is the one who has neither dirham (money) nor wealth." The Prophet said,

The bankrupt of my Ummah is he who would come on the Day of Judgment with prayers, fasting, and zakah; but who had offended one person, slandered another, devoured others' wealth, shed the blood of this person, and beat that person (Sahīh Muslim, no.: 6251).

In fact, everyone in Islam is responsible for their welfare and welfare of their surroundings and subordinates. The prophet (saas) said, as narrated Abdullah bin 'Umar:

I heard Allah's Apostle saying, "Every one of you is a guardian, and responsible for what is in his custody. The ruler is a guardian of his subjects and responsible for them; a husband is a guardian of his family and is responsible for it; a lady is a guardian of her husband's house and is responsible for it, and a servant is a 
guardian of his master's property and is responsible for it." I heard that from Allah's Apostle and I think that the Prophet also said, "A man is a guardian of is father's property and is responsible for it, so all of you are guardians and responsible for your wards and things under your care" (Sah̄̄h Al-Bukhārī, Volume 3, Book 41, Number 592).

Indeed, values and principles that have been central to Islam since the time of the holy Prophet Mohammed (saas) may serve as foundation for notion of Corporate Social Responsibility (CSR) similar to those in the West (Mohammed, 2007). But unlike the West, Islam seeks to bring out the sense of CSR within the organizations and the individuals from within and without, whereas the Western philosophy seeks to ensure a change from without through promulgating laws. In fact, change of attitude comes from within and without. "Abhorrence of wrong-doing comes from within and, thus, the seed of change must be sown from within. Therefore, relying only on laws to change people may not lead to an effective overall and lasting change in business and society" (Parvez, 2000).

At the center of Social Responsibility in Islam, the issue of charity and philanthropy lies. According to Islam, this does not reduce the properties of people, rather it increases. It is seen in Islam as a benefit rather than a cost. Upon CSR depends the survival of both business organizations and society. Thus any social irresponsibility exercised towards each other may create problems for both, which may unfold over a longer time span. Any irresponsibility on the part of a business organization may cost it heavily in the form of improper/illegal waste disposal, exploitation through false advertisement, direct exploitation of employees or customers, or by not addressing poor working conditions, high levels of stress, etc. while onto society, it will come back to haunt or damage the business through different ways and forms such as sabotage by employees, poor morale, or even higher taxes, inflation, reduction in sales and profits, etc. For example, a high level of stress amongst employees will mean more time off work or more people needing healthcare and medication. This will in turn increase pressure on healthcare institutions and subsequently they will demand more resources from the government. To respond to these needs, the government may need to increase individual and corporate taxes or raise money in other ways which will have to be met business 
organizations either directly or indirectly in the longer term (Parvez \& Ahmed, 2004).

The following statements of Islam are of huge importance in this context:

For those who give in charity, men and women, and a loan to God a beautiful loan, it shall be increased manifold (to their credit) and they shall have, (besides) a liberal reward (Al-Qur'an, 57:18).

God deprives usury of all blessing, but will give increase for deeds of charity (Qur'an 2: 276).

By spending in charity, the wealth does not decrease... (Muslim, vol. 4, no: 6264).

"The generous man is near Allah, near paradise, near men and far from hell, but the miserly man is far from Allah, far from Jannah (Paradise), far from men and near Hell. Indeed, an ignorant man who is generous is dearer to Allah than a worshipper who is miserly" (Tirmidhi).

Thus, any costs or benefits that are pushed onto society will come back as greater costs or greater benefits for business organizations. Parvez and Ahmed (2004) illustrated the matter through the following diagram:

Figure 01: Feedback of CSR in the Organization:

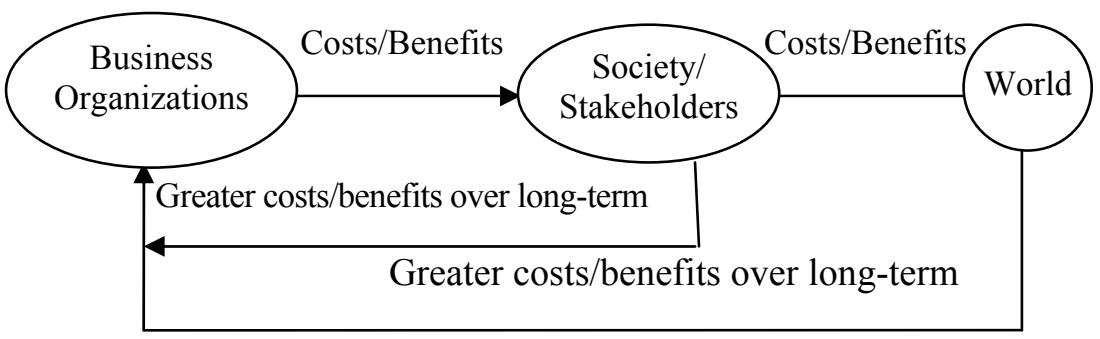

Islamic CSR is founded upon some bases: Tawhìd (Oneness of Allah), Khiläfah (Human Vicegerency), Amānah (Divine Trust), Adl 
(Equilibrium), Ikhtiyār (Freewill), Al-Muasūliyah (Responsibility), Hisāb/Hisbah (Divine Accountability), Amr bil-Ma'rūf wa Nahi' an-alMunkar (Enjoining Good and Forbidding Evil), and Ihsān (Benevolence). The meanings and organizational implications of these axioms are shown in the appendix in Table 01.

The scope of CSR in Islam is comprehensive and well-inclusive as is evidenced by the foregone quotations of the Qur'an and Sunnah. An organization exercises social responsibility in three domains: its (organizational) stakeholders, the natural environment, and the general social welfare. On the basis of the fore-mentioned axioms and principles, the organizational social responsibilities in their major domains will have to be implemented and fulfilled, shown in the appendix in Table 02.

All of these are in fact, Islamic social responsibilities which are vindicated amply by the Qur'an, Sunnah, observations of the Prophet's Companions and performances and perspectives of the pious pundits and predecessors of the Ummah.

\subsection{CSR by a conventional Organization:}

On the basis of study of secondary materials one can easily depict a picture of the context of CSR in Bangladesh as well as the practices of CSR by some conventional organizations. Banking sector can be treated as the pioneer in this aspect. Among the conventional Banks Dutch Bangla Bank has set many remarkable instances of CSR practices. Bangladesh Corporate Blog (2007) a website informs on its $11^{\text {th }}$ Anniversary, Dutch Bangla Bank comes up with a page long display in leading dailies highlighting its CSR activities. It claims that it had donated Tk. 22 crore in 2006 for various social commitments. Some of its headings include Providing support for higher education $\&$ research, Medicare services for rural people, Prothom-alo Ganit Utsab, Plant trees save environment, Anti drug addiction, save the nation from the curse of dowry, developing financial assistance to help develop medical infrastructure, stop acid violence, caring patients living with AIDS, operation facilities for VVF and prolaps uterus etc.

DBBL does not only have the largest network of ATMs (139) in the country, it also has a large and long list of CSR activities too. With a share price soaring around $2000 \mathrm{tk}$. (100 tk. Face value) and increasing by the day, the bank has surely gained investors' and consumers' confidence. 


\subsection{CSR by the selected Islamic Organizations:}

\subsubsection{CSR by IBBL:}

In Bangladesh there are purely 6 Islamic banks, though many scheduled and private commercial banks are opening windows of Islamic banking, which are as follows:

i. Islami Bank Bangladesh Limited

ii. Al-Arafah Islami Bank Limited

iii. EXIM Bank Limited

iv. Shahjalal Islami Bank Limited

v. Social Islami Bank Limited

vi. First Security Islami Bank Ltd

Among these Islamic Banks IBBL is in leading position and it is the first Islamic Bank in Bangladesh. IBBL was established in 1983. As the Bangladesh Government does not have any separate Islamic banking Law or policy, all the Islamic Banks are monitored and guided by their individual council/boards. IBBL is practicing CSR from a long since. One of their significant options is employee welfare. The following list shows a brief of social and financial securities offered by IBBL which are presently in practice too:

a. The recruitment process of the Bank strictly follows "IBBL Recruitment Policy"and maintains transperency in all stages to protect the right of the eligible candidates and the interest of the Bank without discriminating gender, race or socio-economic background.

b. Every year a good number of eligible employees get promotion to the higher rank. Promotions are awarded on merit basis regardless of gender, race or socio-economic background.

c. A good pay-package has been provided to the employees of the Bank. Ratio of the pay between highest \& lowest regular rank is only 14:1. Compulsory 'Provident Fund' (10\% employees' contribution and 10\% Bank's contribution) and provision of Gratuity are also there for the employees of the Bank. 
d. A 'Benevolent Fund' is there for providing emergency financial assistance to the employees. Lumpsum financial grant is provided case to case basis on critical and costly medical treatment ground.

e. 'Super Annuation Fund' has been established for ensuring economic security to the family of the employees in case of death in harness, disability and retirement.

f. To mitigate the housing problem of the employees, the Bank has introduced the house building investment scheme for the employees.

g. The Bank maintains the leave policy for the employees complying with the relevant laws of the land as well as the guidelines of the Central Bank. Leave encashment facilities are also there for the employees.

h. Liveries and uniform are provided to the sub-staffs every year. They are also provided with overtime bills for working after office hours.

i. Full time transport facilities are provided to SVP \& above rancked executives. Executives in the rank of VP and above are also provided with car under "Car Scheme for the Employees of the Bank".

j. To develop professional knowledge, skill and attitude of the employees, the Bank has got its own Traning Academy where training courses are conducted round the year. The employees are also sent to abroad for higher training.

k. The meritorious children of the employees are also awarded with stipend/grant regular basis.

1. Annual family get together, sports \& cultural competetions for the employees and their family members are organized every year for their recreation and to encourage their socio-cultural involvement.

IBBL also operates various welfare activities directly and through Islami Bank Foundation (IBF). During various natural disaster, IBBL came forward with relief activities for the victims directly and through donating into government funds (Prime Minister's/Chief Advisor's Fund). After the recent BDR massacre at Pilkhana (BDR Head Quarter), IBBL sponsored 4 martyred Army families for their 
family expenditure for the period of next 12 years @ Tk. 40,000/- per month.

Under its education support program, IBBL awards scholarship among the meritorious wards of the Bank officials and the meritorious students of Banking \& Finance Department of Dhaka University, Chittagong University and Manarat International University.

As a responsible corporate citizen, IBBL is playing a vital role for development of the society through Islamic Bank Foundation. The welfare activities of Islami Bank Foundation (IBF) may be categorized as under:

1. Educational Program

2. Health and Medicare Program

3. Relief and Rehabilitation Program

4. Income Generation Program

(Details of the activities of IBF are shown in the appendix in Table 03 along with the incurred expenditure)

\subsubsection{CSR Performed by Al Arafah Islami Bank}

The CSR performance of Al Arafah bank is not that much widely spread as yet. As stated in its website (2009) the Bank has a Foundation launching philanthropic activities. Al-Arafah English Medium Madrasah and Al-Arafah Islami Bank Library are major two wings for launching philanthropic activities.

Al-Arafah English Medium Madrasah has been established by the AlArafah Bank Foundation with a view to building next generation according to the ideals of peace and equality of Islam and to establishing banking and other aspects of life in the way of Islam. The prime aim of this Madrasah is to contribute towards building human resource and in the broader sense to ensure human welfare. With the view Al-Arafah Islami Bank Foundation has established an English medium Madrasah at Dhanmondi in 1999. Such institution up to 'O' level of its kind is for the first time in Bangladesh.

As Library is the carrier \& reservoir of knowledge, Al-Arafah Islami Bank has shown that other than generating profit, it can also contribute significantly in the field of providing good source of knowledge by establishing a public library at 32, Topkhana Road, Chittagong Bhaban 
$\left(1^{\text {st }}\right.$ floor), Dhaka, thus strengthening social development. It is situated in sound, healthy surroundings. It harbours 23,000 books of reference for the researchers, students, professionals, bankers, physicians, engineers, politicians, writers or journalists, even for the kids. It is open to all from the year 2000 and well located \& accessible to everybody. It has an exceptional collection of books on religion, economics, banking, computer science, business administration, sociology, English \& Arabic language and juvenile literature in Bangla, English, Urdu \& Arabic, which are very rare.

\subsubsection{CSR Performed by EXIM Bank}

EXIM Bank has a remarkable contribution to the social development. In the fashion of social commitment this Bank is discharging some significant social responsibilities. As stated in its website (Accessed on $28 / 3 / 2010$ ) at least $2 \%$ of its annual profit of every year is put aside for the foundation to conduct Corporate Social Responsibility (CSR) activities. The mainstream CSR activities that are carried out through this foundation are:

- Healthcare service.

- Scholarship program for brilliant poor student.

- Education Promotion Scheme (Interest free loan).

- Helping people affected by natural calamities.

- Helping people in slum areas.

- Donation to educational institutions to setup computer lab.

- Beautification of Dhaka City.

\subsubsection{Healthcare Service}

A 5 storied building having 10,000 sft floor space at 840 Kazi Para, Rokeya Sarani,Mirpur, Dhaka-1216 has been hired to set up Exim Bank Hospital. The decoration of this hospital is going on in full swing. A doctor has been recruited who is working as a resident director of the hospital. Other doctors and hospital staffs have been in the process of selection through recruitment notice already published in the national dailies. They will be appointed as soon as the decoration of the hospital is complete. 


\subsubsection{Scholarship Program for Brilliant Poor Student}

This is a stipend package for poor and meritorious students that take care of the beneficiaries throughout their student life. EXIM Bank Scholarship Program, launched in 2006 with 61 poor and meritorious students selected from different reputed educational institutions of Dhaka City including Govt. Laboratory High School, Viqarunnissa Noon School and College, Dhaka University, BUET, Dhaka Medical College, etc. enrolled as many as 1000 students from around 150 reputed educational institutions across the country by 31 December 2008. They are enrolled in the this program to be taken care of for their whole educational life subject to their fulfillment of the eligibility criteria that include satisfactory academic results, non-involvement in student politics, financial insolvency etc. So far Tk. 19.3 million has been disbursed as scholarship under this program.

\subsubsection{Education Promotion Scheme (Interest free loan)}

Under Education Promotion Scheme, quard or interest-free loan is provided for poor and meritorious students to help them bear monthly educational expenditure including academic expenses, food, accommodation, etc. The quard is disbursed to the selected students in monthly installments till their accomplishing the master degree. Under this program the students are required to repay the amount (only the principal amount) in long-term monthly installments after they have joined a confirmed job accomplishing their education properly. By 31 December 2008, Tk. 19.7 million was sanctioned to take care of around 138 poor and meritorious students from a number of reputed educational institutions like Dhaka University, Chittagong University, Dhaka Medical College, BUET, Bangladesh Agricultural University, Shahjalal University of Science and Technology etc.

\subsubsection{Helping People Affected by Natural Calamities}

Another vital area we are dealing with as part of our CSR activities is helping people survive natural calamities. Under this welfare program, EXIM Bank provides relief in cash and kind for flood, fire or cyclone victims and cold-stricken people. The aim of these CSR activities is to help the target group overcome their provisional handicap and contribute to the socio-economic growth as soon as possible.

\subsubsection{Helping People in Slum Areas}

Besides natural calamities, fire breaks out sometimes in slum areas that guts the shanties and renders the affected people totally helpless. In 
that situation, we help the victims fight against the hard days and return to normal life.

\subsubsection{Donation to Educational Institutions to Setup Computer Lab}

We have donated to Dhaka University and Chittagong University to set up two computer labs that help the students of those universities acquire ICT knowledge. This will certainly help the students to be ready to take the challenges of this information society.

\subsubsection{Beautification of Dhaka City}

In response to the call of the Dhaka City Corporation, EXIM Bank has been sharing a good portion of the mammoth task of beautifying the capital since 2005. To make the capital a modern city enriched with adequate urban amenities, EXIM Bank always joins hands with the government.

\subsubsection{CSR Performed by other Islamic Banks:}

The CSR activities of other Islamic Banks, namely Shahjalal Islami Bank Limited, Social Islami Bank Limited, and First Security Islami Bank limited are not significantly recorded. As per the information provided in their respective websites and annual reports, those are mostly confined to education scholarship offered to the brilliant students, charitable activities to the natural disaster affected people, and some medical and environmental services. The CSR performances of these organizations are shown in Figure 03 and in the appendix in Table 05 .

\subsection{CSR Activities of Islamic Pharmaceutical Companies:}

This paper surveyed two pharmaceutical companies, namely Ibn Sina Pharmaceuticals and Biopharma Laboratories. These companies have huge CSR activities, especially the Ibn Sina, as transpired in the following analysis. But the CSR of Biopharma are largely unrecorded and thus not significantly discussed in the paper.

\subsubsection{CSR of Ibn Sina Trust}

Ibn Sina Trust has a number of concerns like Pharmaceuticals, Hospitals and Medical College. It has spent about Tk. 80 Crore (TK 800 million) since it began in 1980 for the purpose of ' $D a$ 'wah work and humanitarian causes. A third of the annual income is kept aside for the purpose while another is kept as reserves. The remaining portion is kept for future development purposes. 


\subsubsection{Community welfare activities}

The trust has three Medical Centers in Dhaka (The Capital City of Bangladesh). It also gives financial assistance to various other free medical centers located at different parts of Bangladesh.

\subsubsection{Free Investigation and Free Hospitalization}

The trust has a separate budget which helps to facilitate free investigation and hospitalization services for those in need. In addition, The Ibn Sina Trust has worked for CSR by some programs at free of cost which has been shown in the appendix in Table 04.

2.4 CSR Activities of Islamic Cooperatives and Real Estate Companies:

This paper also surveyed one Cooperative and one Real Estate Company (Reliance Cooperative and Keari Ltd) It has been found that the CSR activities of these companies are largely confined to the charitable contribution to the natural disaster affected areas, education stipend to bright students, general welfare of the internal employees and environmental protection.

\section{Some other findings on the Basis of Questionnaire:}

A structured close ended questionnaire was used to find the opinion of the employees regarding CSR of their respective Organizations. Using 5 point likert scale data has been collected from 3 employees from each of the organizations (Total size is 10). Table 5, in the appendix, shows the opinion of the respondents with their mean and SD values.

Table 5 explains question No. 7, 11, and 18 has the greater value as they experienced minimum deviation. In the question No. 7, $43.3 \%$ of the respondents as they strongly agree in the point 'significant contribution in the social development' by their organizations when $56.7 \%$ of the respondents opined as agree for the same. As Bangladesh regularly experiences natural disaster, Question No. 11 was whether the organization contributes for the victims of Natural Disaster. $43.3 \%$ strongly agreed and $56.7 \%$ agreed on this point. In the question No. $18,60 \%$ of the respondents agreed and $40 \%$ strongly agreed that government should encourage companies to be more concerned for CSR. Some similarities are observed in the question No. 16 and 17 where $40 \%$ of the respondents viewed CSR with business motive is not harmful and the same percentage gave their views that they are practicing CSR with business motive. 
The mean value of each of the scale points can be shown in a figure which indicates the extent of individual significance of each of the scale points. As shown in Figure 02, the point 'Agree' received the highest $\%$ score i.e. $43 \%$. As most of the statements were in favor of CSR this is a good sign which mean Islamic Organizations have a very good command on the practices of CSR.

Figure 03 shows the distribution of average Social responsibility of Islamic organizations of Bangladesh. Accumulating and averaging the respondents' opinion it has been found that Ibn Sina scores highest and then Al Arafah Islami Bank and Islami Bank Bangladesh Limited. In the figure vertical axis indicates the average scores of the statements and horizontal axis indicates the Islamic organization.

Figure 02: Percentage distribution of the individual status of scale points.

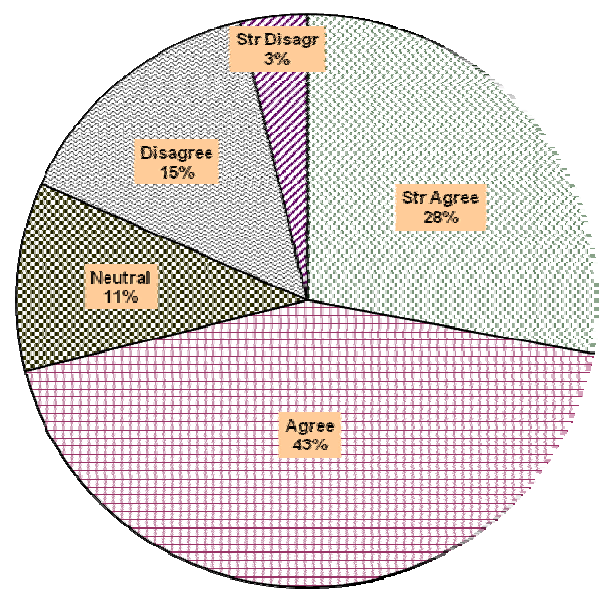

Figure 03: Distribution of average Social Responsibility of Islamic organizations of Bangladesh. 


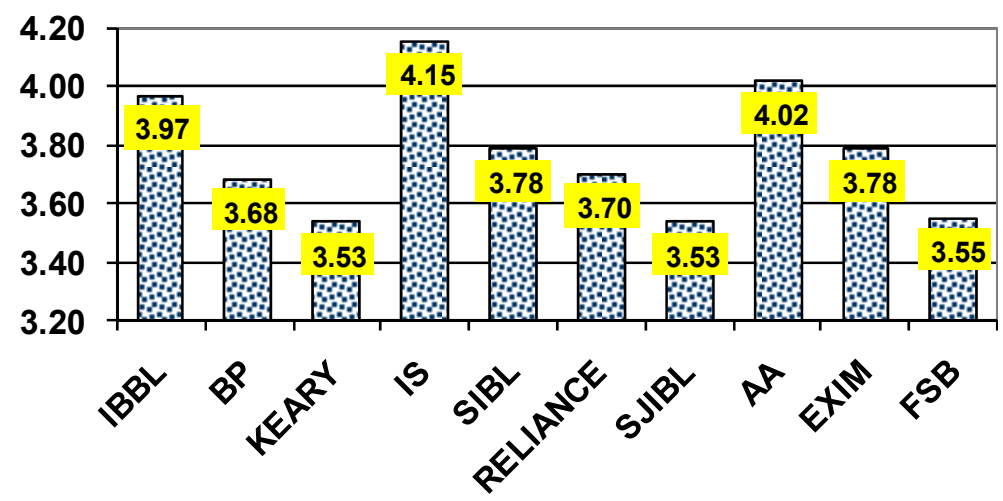

\section{Policy Recommendation:}

Though the Islamic organizations are contributing a lot to the society, this is a never ending process. They should keep on keeping on the practice of CSR and try to expand it in a substantial manner so that they can reach to the common people in the better way than those of conventional business organizations. This is not a matter of criticism that business organizations are doing CSR with a business motive. CSR will definitely approach the organization to the society as well as to the customers in the society. It can be thought in a more positive way. No matter what the motive is but it is becoming a support for the people in the society and the people are getting benefit from it. In case of Islamic organizations there are two goals: Success herein (Acceptability in the Society, Accordingly Business Profit (through revenue), and Success hereafter (having the Placement in Jannah).

\section{Conclusion:}

This study has shown that evidence on CSR by Islamic Organizations is not that much limited in Bangladesh. The evidence that is available indicates that some of the top most Islamic organizations are far ahead of practicing CSR. Particularly Banks (Islami Bank and Al Arafah Bank Foundation) and one Trust (Ibn Sina Trust) have contributed a lot so among the private businesses.

In this context, and given the mission (from both internal and external sources) taken by the corporations in achieving a viable growth rate, it seems that a considerable expansion will take place in CSR involvement in the near future. There are huge potential for 
undertaking CSR that would combine business interests and broader social concerns and needs.

In fine, it is expected that, if Islamic Organizations get the support from the Government at least the psychological support i.e. the friendly attitude toward them, they can contribute a lot to the development of Bangladesh through CSR. Waqf (an inalienable religious donation in Islamic law) can be a great tool for CSR in the total socio economic development of a state like Bangladesh where more than $80 \%$ of the Muslim majority is in existence.

\section{Reference}

Abdullah, Ahmad Ibrahim Bin Haji, Stakeholders Management: The Islamic Perspective Corporate Social Responsibility, Dissertation for the Degree of Master of Business Administration under International Islamic University Malaysia, pp. 1-45.

Ahmad, Mushtaq, Business Ethics in Islam, published jointly by International Institute of Islamic Thought (USA) and Islamic Research Institute (Pakistan), 1995, pp. 53-100, 127-137.

Al Mahmud, Abdullah, 'A Comparative Study on Performance Evaluation of Conventional Banks and Islamic Banks in Bangladesh with Special Reference to Islami Bank Bangladesh Limited', Thoughts on Economics, Vol. 18, No. 05, October-December 2008.

Barney, Jay B. \& Griffin, Ricky W. The Management of Organizations, Houghton Mifflin Company, 1992.

Beekun, Rafik Issa, Islamic Business Ethics, The International Institute of Islamic Thought, VA, USA, 1997, pp. 20-28, 38-56.

Friendman, M. (1996), The Social Responsibility of Business is to increase profit. In Dusuki, A.W., What Does Islam Say About Corporate Social Responsibility? Review of Islamic Economics, Vol 12, No 1, May 2008

Mohammed, J. A., Corporate Social Responsibility in Islam, Ph D work under Auckland University of Technology, New Zealand, 2007, pp. 55-152, 179217. 
Matin Nilufar, 'Corporate Social Responsibility and Natural Disaster Reduction: Insights from Bangladesh', 2002.<http:// www.research4development.info/PDF/Outputs/Mis_SPC/R7893CSRBanglad $\underline{\text { esh.pdf }}>29 / 03 / 2010$

Meeting Changing Expectations, The WBCSD's Definition of CSR, World Business Council for Sustainable Development, Geneva< http:// www.wbcsd.org/templates/TemplateWBCSD5/layout.asp?type=p\&MenuId $=$ $\underline{\text { MTE0OQ }>29 / 03 / 2010}$

Mondol Edward Prabir, 'Why Corporate Responsibility? - The Context of Bangladesh', 2009.

Naqvi, S. N. H, Ethics and Economics: An Islamic Synthesis, The Islamic Foundation, Manchester, Leicester, UK, 1981. <http://www.ammado.com /nonprofit/105776/articles/9858 26/3/2010>

Parvez, Z., 'Building a new society: an Islamic approach to social change', Markfield: Revival Publications, 2000.

Parvez, Zahid \& Ahmed, Pervaiz, 'An Islamic perspective on the lack of social responsibility in business organisations', Working Paper Series 2004, Number WP005/04, University of Wolverhampton Business School, University of Wolverhampton, UK., pp. 9-13.

Brochure, The Ibn Sina Trust (2009)

CSR of Al Arafah Bank Limited < http://www.al-arafahbank.com/SocialResponsibilities.php $>, 31 / 3 / 2010$

Dutch Bangla Bank Social Responsibility $<$ http:// bangladeshcorporate.blogspot .com/2007/06/dutch-bangla-banks-corporatesocial.html $>, 31 / 3 / 2010$

Islami Bank Foundation (2009)

Social Commitment, EXIM Bank Limited. <http://www.eximbankbd.com /php/static/social.php> $>$ 28/3/2010 
IIUC Studies, Vol. 7

Appendix

Table 1: Principles/Axioms of CSR in Islam

\begin{tabular}{|c|c|c|c|}
\hline \multicolumn{4}{|c|}{ Principles/Axioms of CSR in Islam } \\
\hline$S L$ & $\begin{array}{l}\text { Principles/ } \\
\text { Axioms }\end{array}$ & Definitions/Descriptions & $\begin{array}{l}\text { Implications } \\
\text { Organizations }\end{array}$ \\
\hline 1) & Tawhìd & $\begin{array}{l}\text { It implies that all aspects } \\
\text { of human life constitutes a } \\
\text { homogeneous whole } \\
\text { without making any } \\
\text { religious and secular } \\
\text { divide while to be guided } \\
\text { divinely for all possible } \\
\text { human actions. It also } \\
\text { implies that everything is } \\
\text { Allah's creation and thus } \\
\text { everything is equal in His } \\
\text { sight }(6: 38) \text {. }\end{array}$ & \multirow{3}{*}{ 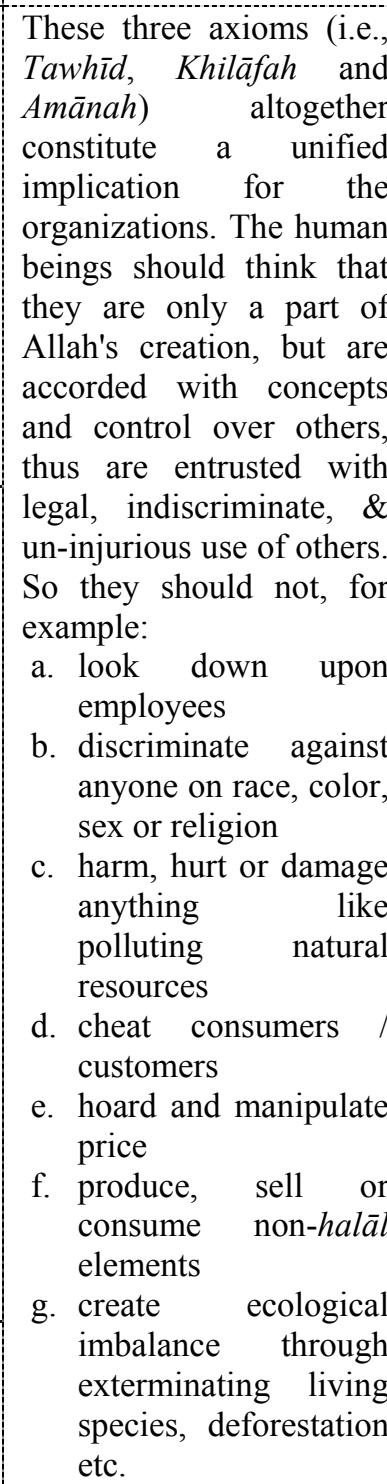 } \\
\hline 2) & Khilāfah & $\begin{array}{l}\text { Human beings have a } \\
\text { privileged position among } \\
\text { God's creations and are } \\
\text { chosen as khalifah, or } \\
\text { "vice-regents" (2:30). } \\
\text { Therefore, mankind is } \\
\text { responsible of caring for } \\
\text { God's earthly creations. } \\
\text { The Qur'an also warns } \\
\text { humans against arrogance } \\
\text { because we are no better } \\
\text { than other creatures (6:38). } \\
\text { The Prophet (saas) said: } \\
\text { "The world is sweet and } \\
\text { green (alluring) and verily } \\
\text { Allah is going to install } \\
\text { you as vicegerent } \\
\text { (khalīfah) on it in order to } \\
\text { see how you act" (Sahīh } \\
\text { Muslim). }\end{array}$ & \\
\hline 3) & Amānah & $\begin{array}{l}\text { According to this, human } \\
\text { beings are not the absolute } \\
\text { owner of earthly resources. } \\
\text { They are entrusted with }\end{array}$ & \\
\hline
\end{tabular}




\begin{tabular}{|c|c|c|c|}
\hline & & $\begin{array}{l}\text { those and are allowed to } \\
\text { enjoy and use those for } \\
\text { their benefits, but not to } \\
\text { exploit or abuse those in } \\
\text { any harmful way. Because } \\
\text { these are Allah's Amānah } \\
\text { (trust) for them. If they } \\
\text { abuse or embezzle it that } \\
\text { will be a breach of their } \\
\text { trust (33:72-73). }\end{array}$ & \\
\hline 4) & 'Adl & $\begin{array}{l}\text { 'Adl or equilibrium is a } \\
\text { sense of balance among } \\
\text { the various aspects of } \\
\text { man's life in order to } \\
\text { produce the best social } \\
\text { order. As Allah created } \\
\text { everything in balance } \\
(25: 2,54: 49) \text {, it should be } \\
\text { maintained in all socio- } \\
\text { economic affairs of a } \\
\text { Muslim society through } \\
\text { moderate approach and } \\
\text { without any discrimination } \\
\text { or exaggeration. }\end{array}$ & $\begin{array}{l}\text { Organizations should } \\
\text { always practice } \\
\text { moderation in all their } \\
\text { activities. For example: } \\
\text { a. Equitable distribution } \\
\text { of resources } \\
\text { b. Moderate profit/price } \\
\text { c. Equal share of profit } \\
\text { \& loss } \\
\text { d. Social } \\
\text { business/marketing }\end{array}$ \\
\hline 5) & Ikhtiyār & $\begin{array}{l}\text { Ikhtiyār or freewill refers } \\
\text { to man's ability to act } \\
\text { without external coercion } \\
\text { and choose his behavior to } \\
\text { be either ethical or } \\
\text { unethical }(13: 11) \text {. } \\
\text { However, to have Allah's } \\
\text { blessings, s/he must } \\
\text { manage his/her freewill to } \\
\text { act according to the moral } \\
\text { code laid out by Allah in } \\
\text { His divine } \\
\text { commandments. }\end{array}$ & $\begin{array}{l}\text { Freewill is to be digested } \\
\text { into compliance with } \\
\text { Allah's will for CSR by } \\
\text { organizations. Like: } \\
\text { a) Contributing to } \\
\text { social wellbeing } \\
\text { b) Fulfilling social } \\
\text { obligations } \\
\text { c) Care for less- } \\
\text { fortunate in society }\end{array}$ \\
\hline 6) & $\begin{array}{l}\text { Muasūliyah/ } \\
\text { Fardh }\end{array}$ & $\begin{array}{l}\text { Muasüliyah/Fardh or } \\
\text { responsibility implies that } \\
\text { man is free to go but with } \\
\text { responsibility. It sets a } \\
\text { limit to his/her activities } \\
\text { and makes her/him }\end{array}$ & $\begin{array}{l}\text { All organizations are } \\
\text { responsible for their } \\
\text { activities, and will have to } \\
\text { account to people and to } \\
\text { Allah for their }\end{array}$ \\
\hline
\end{tabular}


IIUC Studies, Vol. 7

\begin{tabular}{|c|c|c|c|}
\hline & & $\begin{array}{l}\text { responsible for all actions } \\
\text { for which } \mathrm{s} / \text { he will be held } \\
\text { accountable }(4: 85) \text {. }\end{array}$ & \multirow{2}{*}{$\begin{array}{l}\text { performances. } \\
\text { a. Illegitimate products } \\
\text { or services should } \\
\text { not be offered } \\
\text { b. In case any of } \\
\text { problem, the money } \\
\text { should be refunded } \\
\text { to buyers/consumers } \\
\text { c. Creating social } \\
\text { public awareness } \\
\text { d. Providing ribā-free } \\
\text { education load }\end{array}$} \\
\hline 7) & Hisāb/Hisbah & $\begin{array}{l}\text { It denotes that individuals } \\
\text { will be accountable to } \\
\text { Allah for all of their } \\
\text { actions, including the } \\
\text { tiniest ones, on the Day of } \\
\text { Judgment ( } 4: 86,99: 7-8) \text {. } \\
\text { This divine accountability } \\
\text { is the basis for all actions } \\
\text { of a Muslim and it forces } \\
\text { him to act ethically in all } \\
\text { walks of life and fulfill his } \\
\text { social responsibilities. }\end{array}$ & \\
\hline 8) & $\begin{array}{l}\text { Amr bil- } \\
\text { Ma'rūf wa } \\
\text { Nahi' an-al- } \\
\text { Munkar }\end{array}$ & $\begin{array}{l}\text { Amr bil-Ma'rüf wa Nahi' } \\
\text { an-al-Munkar or Bidding } \\
\text { for good and forbidding } \\
\text { from evil is an individual } \\
\text { responsibility to install in } \\
\text { the society that what is } \\
\text { right and eradicate from } \\
\text { the society that what is } \\
\text { wrong (9:71, 3:110). It } \\
\text { comprises a prescription } \\
\text { towards positive actions } \\
\text { and a proscription against } \\
\text { negative actions. }\end{array}$ & $\begin{array}{l}\text { An organization should } \\
\text { not only keep away from } \\
\text { unethical and } \\
\text { irresponsible activities, } \\
\text { but should also prevent } \\
\text { others from doing so. } \\
\text { a. Resisting } \\
\text { production/sale the } \\
\text { harām/adulterated/spoi } \\
\text { led goods } \\
\text { b. Initiating } \\
\text { alternatives to nudity / } \\
\text { hedonism } \\
\text { culture }\end{array}$ \\
\hline 9) & Ihsān & $\begin{array}{l}\text { Ihsān or benevolence is an } \\
\text { action that benefits persons } \\
\text { other than those from } \\
\text { whom the action proceeds } \\
\text { without any obligation. }\end{array}$ & $\begin{array}{l}\text { It is just giving } \\
\text { someone/something more } \\
\text { that its entitlement, like } \\
\text { giving extra wage to } \\
\text { workers etc. }\end{array}$ \\
\hline
\end{tabular}

(Source: Personal Analysis) 
Table 2: Major domains/stakeholders of CSR \& their issues of concerns

\begin{tabular}{|c|c|c|c|c|}
\hline $\mathrm{SL}$ & $\begin{array}{l}\text { Major } \\
\text { Domains }\end{array}$ & Focus Areas & Stakeholders & Issues of Concern \\
\hline \multirow{5}{*}{ 1) } & \multirow{5}{*}{$\begin{array}{l}\text { Organizati } \\
\text { onal } \\
\text { Stakehold } \\
\text { ers }\end{array}$} & \multirow{2}{*}{$\begin{array}{l}\text { Firm- } \\
\text { Employee } \\
\text { Relationship }\end{array}$} & Employees & $\begin{array}{l}\text { Hiring-Firing- } \\
\text { Promotion based on } \\
\text { justice, Fair Wages, } \\
\text { Religious Freedom, } \\
\text { Accountability, } \\
\text { Preservation of } \\
\text { Privacy, \& } \\
\text { Benevolence etc. }\end{array}$ \\
\hline & & & Firms & $\begin{array}{l}\text { Honesty, Sincerity, } \\
\text { Truthfulness, } \\
\text { Loyalty } \\
\text { Commitment, } \\
\text { Secrecy, Conflicts of } \\
\text { Interests, Skills } \\
\text { Training and } \\
\text { Qualifications, and }\end{array}$ \\
\hline & & \multirow{3}{*}{$\begin{array}{l}\text { Other } \\
\text { Stakeholders }\end{array}$} & Suppliers & $\begin{array}{l}\text { Fair } \\
\text { Singing a Contract, } \\
\text { Free } \\
\text { Mechanism, } \\
\text { Middleman Worket } \\
\text { Ethically, }\end{array}$ \\
\hline & & & $\begin{array}{l}\text { Buyers \& } \\
\text { Consumers }\end{array}$ & $\begin{array}{l}\text { Use of Incorrect } \\
\text { Weight \& Measure, } \\
\text { Hoarding \& Price } \\
\text { Manipulation, } \\
\text { Adulterated \& } \\
\text { Spoiled Products, } \\
\text { Swearing to Support } \\
\text { a Sale, Purchase of } \\
\text { Stolen Properties, } \\
\text { Ribā/Interest, False } \\
\text { Advertising \& } \\
\text { Misrepresentation, }\end{array}$ \\
\hline & & & Debtors & $\begin{array}{l}\text { Benevolence by } \\
\text { lenders and urgency } \\
\text { on debtors' part to } \\
\text { repay at the earliest. }\end{array}$ \\
\hline
\end{tabular}




\begin{tabular}{|c|c|c|c|c|}
\hline & & & The Needy & $\begin{array}{ll}\text { Sadaqah } & \text { from } \\
\text { wholesome \& } & \text { halāl } \\
\text { income } & \end{array}$ \\
\hline & & & Competitors & $\begin{array}{l}\text { Mutual help, Market } \\
\text { is open, Non- } \\
\text { Monopolistic } \\
\text { business } \\
\text { environment etc. }\end{array}$ \\
\hline & & & $\begin{array}{l}\text { Owners/Investors/ } \\
\text { Partners }\end{array}$ & $\begin{array}{l}\text { Clarity, Fair \& } \\
\text { Proportionate Share } \\
\text { of Profit \& Loss, } \\
\text { Mutual Counseling } \\
\& \text { Consent, Haläl } \\
\text { Investment etc. }\end{array}$ \\
\hline & & & General Public & $\begin{array}{lr}\text { Fair } & \text { Pricing, } \\
\text { Production } & \text { of } \\
\text { essentials \& } & \text { non- } \\
\text { Injurious } & \text { items, } \\
\text { Ethical Consumption }\end{array}$ \\
\hline & & $\begin{array}{l}\text { Treatment } \\
\text { of Animals }\end{array}$ & & $\begin{array}{l}\text { Taking care of } \\
\text { animals without } \\
\text { inflicting any harm } \\
\text { or injury, Showing } \\
\text { kindness } \\
\text { consideration, } \\
\text { Protecting innocent } \\
\text { animals }\end{array}$ \\
\hline 2) & Natural & & Basic Principles & $\begin{array}{l}\text { Avoiding anything } \\
\text { causing pollution to } \\
\text { the natural resources } \\
\text { or disturbing } \\
\text { environmental purity } \\
\text { and calmness. A } \\
\text { person polluting the } \\
\text { environment is } \\
\text { responsible for its } \\
\text { restoration. }\end{array}$ \\
\hline & $\begin{array}{l}\text { Environm } \\
\text { ent }\end{array}$ & & & $\begin{array}{l}\text { Wastage/Extravagan } \\
\text { ce of water is } \\
\text { prohibited, Dumping }\end{array}$ \\
\hline
\end{tabular}




\begin{tabular}{|c|c|c|}
\hline \multirow[t]{5}{*}{$\begin{array}{l}\text { Environment } \\
\text { al Pollution }\end{array}$} & Water & $\begin{array}{l}\text { industrial and other } \\
\text { garbage, discharges, } \\
\text { wastes, exhausts, } \\
\text { cleansing materials, } \\
\text { and other toxic and } \\
\text { harmful substances } \\
\text { into water body, } \\
\text { Everybody does } \\
\text { have a right to all } \\
\text { water bodies without } \\
\text { monopoly \& } \\
\text { discrimination. }\end{array}$ \\
\hline & Air & $\begin{array}{l}\text { Polluting the air } \\
\text { through dumping } \\
\text { wastes \& discharges } \\
\text { in the open space is } \\
\text { prohibited, Emission } \\
\text { of Carbon dioxide is } \\
\text { restricted, blocking } \\
\text { air from somebody's } \\
\text { residence is not } \\
\text { allowed etc. }\end{array}$ \\
\hline & The Land \& Soil & $\begin{array}{l}\text { Everything causing } \\
\text { infertility, erosion, } \\
\text { and degradation of } \\
\text { the lands should be } \\
\text { prevented. }\end{array}$ \\
\hline & Sight \& Sound & $\begin{array}{l}\text { Nothing is allowed } \\
\text { to be done which } \\
\text { may cause sight and } \\
\text { sound pollution like } \\
\text { excessive advertising } \\
\text { in sign/bill/other } \\
\text { boards creating } \\
\text { abnormal sounds and } \\
\text { causing un-necessary } \\
\text { noise is prohibited. }\end{array}$ \\
\hline & Others & $\begin{array}{l}\text { The Prophetic } \\
\text { Declaration: "There } \\
\text { shall be no damage } \\
\text { and no infliction of } \\
\text { damage." }\end{array}$ \\
\hline
\end{tabular}


IIUC Studies, Vol. 7

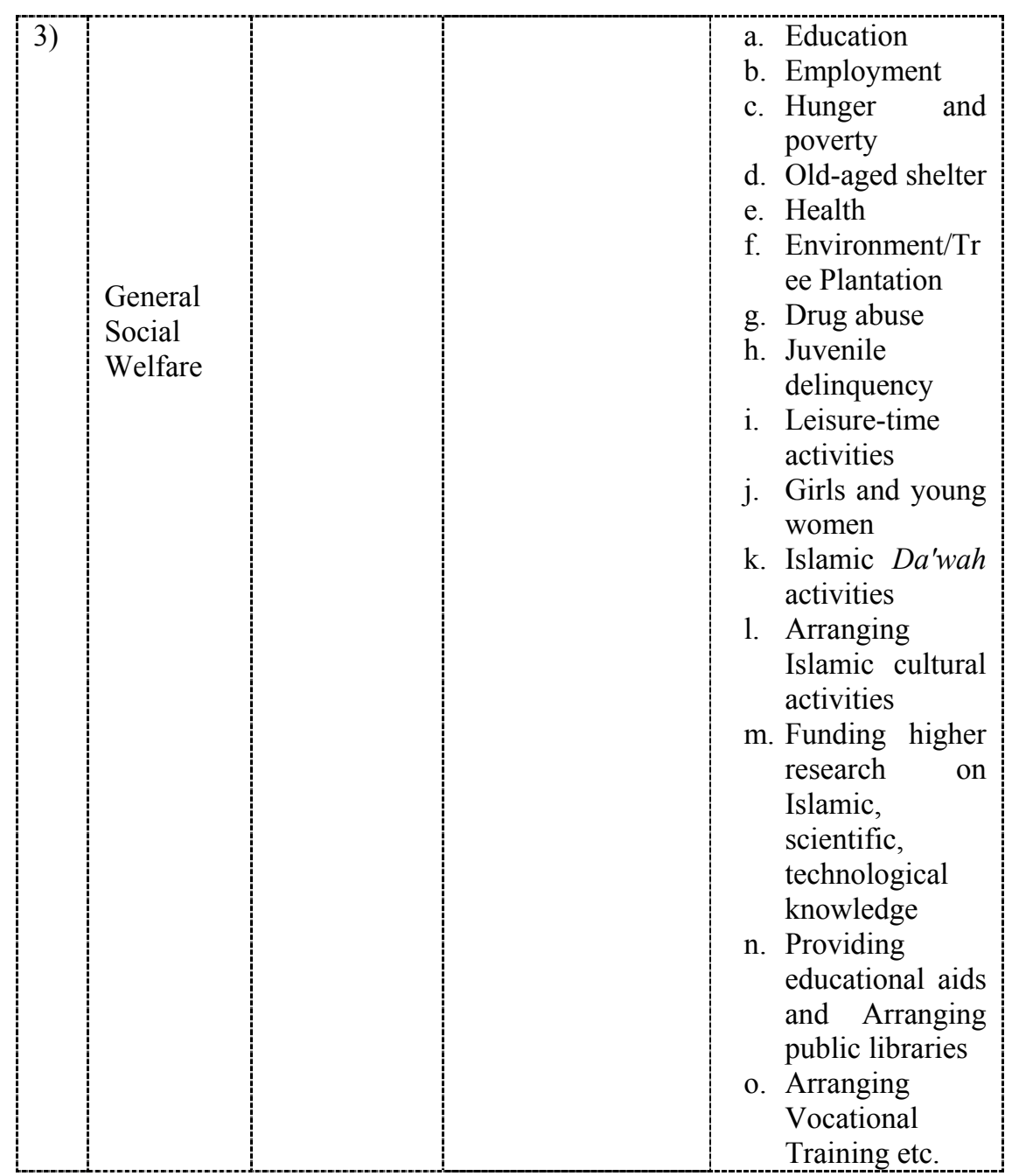

(Source: Beekun and Personal Analysis) 
Table 3: Details of the activities of IBF and the expenditure incurred during the last 5 (five) years

\begin{tabular}{|c|c|c|}
\hline Program & Activities & $\begin{array}{l}\text { Expenditure of } \\
\text { last } 5 \text { year from } \\
2003-04 \text { to } \\
2007-08 \\
\text { (Fig. In million } \\
\text { taka) }\end{array}$ \\
\hline \multirow[t]{2}{*}{$\begin{array}{l}\text { Education } \\
\text { Program }\end{array}$} & $\begin{array}{l}\text { a) } \quad \text { Establishment of own } \\
\text { Educational Institutions: } \\
\text { - } \quad \text { Medical College }-1 \\
\text { - } \quad \text { Nursing Training Institute }-1 \\
\text { - } \quad \text { Institute of Health Technology }-1 \\
\text { - } \quad \text { Institute of Technology }-6 \\
\text { - } \quad \text { School \& College }-2 \\
\text { - } \quad \text { Girls Madrasha }-1 \\
\text { - } \text { Cultural Centre }-1\end{array}$ & \multirow[t]{2}{*}{441.69} \\
\hline & $\begin{array}{l}\text { b) } \\
\text { Stipend \& Scholarship Program } \\
\text { c) } \\
\text { institutions }\end{array}$ & \\
\hline $\begin{array}{l}\text { Health \& } \\
\text { Medicare }\end{array}$ & $\begin{array}{l}\text { a) Establishment of own Health } \\
\text { Institutions: } \\
\text { - Hospital -6 } \\
\text { - I B Community Hospital -7 } \\
\text { - Homeopathy Clinic -1 } \\
\text { b) Launching verious health program: } \\
\text { - Free eye camp, mobile eye camp, free }\end{array}$ & 289.72 \\
\hline
\end{tabular}


IIUC Studies, Vol. 7

\begin{tabular}{|c|c|c|}
\hline \multirow[t]{4}{*}{ Progra } & $\begin{array}{l}\text { circumsession programme etc. } \\
\text { - Distribution of tube-well and sanitary } \\
\text { lantrine etc. }\end{array}$ & \\
\hline & c) Midwifery Training Program & \\
\hline & d) Assistance to charitable dispensaries & \\
\hline & e) Assistance to the poor patients & \\
\hline \multirow[t]{3}{*}{$\begin{array}{l}\text { Humaniterian } \\
\text { Assistance } \\
\text { and Relief \& } \\
\text { Rehabilitation } \\
\text { Program }\end{array}$} & $\begin{array}{l}\text { a) Establishment of Institutions: } \\
\text { - Distressed Women Rehabilitation } \\
\text { Centre }-1 \\
\text { - Service Centres }-5 \\
\text { (cyclone centre cum community places) } \\
\text { - Monorom : IB Craft \& Fashions - } 1 \\
\text { (sales outlet of garments, handicrafts } \\
\text { and other items produced by the } \\
\text { distressed women) }\end{array}$ & \multirow[t]{3}{*}{83.39} \\
\hline & $\begin{array}{l}\text { b) Financial assistance to needy and } \\
\text { heavily indebted individuals }\end{array}$ & \\
\hline & $\begin{array}{l}\text { c) Relief \& rehabilitation program } \\
\text { during natural calamities }\end{array}$ & \\
\hline \multirow[t]{2}{*}{$\begin{array}{l}\text { Income } \\
\text { Generation } \\
\text { Program }\end{array}$} & $\begin{array}{l}\text { Micro investment activities for the } \\
\text { hardcore poor and downtrodden } \\
\text { population of the society. }\end{array}$ & 43.19 \\
\hline & Total Taka in Million & 857.99 \\
\hline
\end{tabular}

(Source: Islami Bank Foundation (IBF)) 
Table 4: Scheme wise Activities

\begin{tabular}{|c|c|}
\hline Scheme & Activities \\
\hline Susmita & $\begin{array}{l}\text { Free operation and treatment for cleft-lipped } \\
\text { children. }\end{array}$ \\
\hline Walk Well & Free operation and Treatment for club feet babies \\
\hline IOL Camp & Free intra-ocular lens operation and treatment \\
\hline Student stipend & $\begin{array}{l}\text { The trust offers annual stipend to poor and } \\
\text { meritorious students belonging to various } \\
\text { educational institutions within the country. The } \\
\text { annual expenditure for this cause is increasing } \\
\text { gradually. }\end{array}$ \\
\hline $\begin{array}{l}\text { Financial Assistance } \\
\text { to the Distressed }\end{array}$ & $\begin{array}{l}\text { The trust offers financial assistance to disabled, } \\
\text { unemployed, and widowed people, and to families } \\
\text { who are in distress. }\end{array}$ \\
\hline $\begin{array}{l}\text { Cooperation in } \\
\text { Spreading Education }\end{array}$ & $\begin{array}{l}\text { The trust extends its cooperation every year to } \\
\text { locally run schools and madrasahs which work to } \\
\text { spread Islamic education and moral standards } \\
\text { within this society. }\end{array}$ \\
\hline $\begin{array}{l}\text { Islamic } \quad \text { Dawa } \\
\text { Program }\end{array}$ & $\begin{array}{l}\text { The trust has a separate budget for the free } \\
\text { distribution of copies of the Holy Quran, Hadith } \\
\text { and Islamic Publications. }\end{array}$ \\
\hline Qard-E-Hasana & $\begin{array}{l}\text { The Trust has established the Qard-E-Hasana } \\
\text { scheme from which people with monetary } \\
\text { problems can have benefits. }\end{array}$ \\
\hline Staff Welfare Program & $\begin{array}{l}\text { This program is designed to continuously improve } \\
\text { the welfare of the staff. Large investments have } \\
\text { been made in this area. }\end{array}$ \\
\hline $\begin{array}{l}\text { Financial Help in case } \\
\text { of Natural Calamities }\end{array}$ & $\begin{array}{l}\text { IST extends its cooperation towards giving relief } \\
\text { through distribution of materials mand drugs free } \\
\text { of charge and makes arrangements for } \\
\text { rehabilitation during natural calamities. To date, a } \\
\text { large amount of financial assistance has been given } \\
\text { to this cause. }\end{array}$ \\
\hline
\end{tabular}

(Source: Table is prepared by the authors (information collected from a Brochure published by The Ibn Sina Trust)) 
IIUC Studies, Vol. 7

Table-5: Frequency Distribution of the Opinion of Employees work in the Cell relevant with CSR

\begin{tabular}{|c|c|c|c|c|c|c|c|c|c|}
\hline \multirow[b]{2}{*}{$\begin{array}{l}\mathscr{0} \\
\stackrel{0}{0} \\
\frac{0}{0}\end{array}$} & & \multicolumn{5}{|c|}{ Points in the Likert Scale } & \multirow[b]{2}{*}{$\stackrel{-1}{\stackrel{0}{ٍ ٍ ~}}$} & \multirow[b]{2}{*}{ "3. } & \multirow[b]{2}{*}{$\mathscr{\theta}$} \\
\hline & & 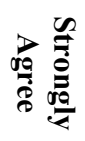 & 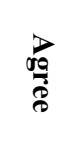 & 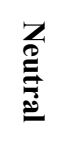 & 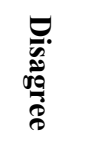 & 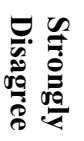 & & & \\
\hline \multirow{2}{*}{$\begin{array}{l}\text { You believe in } \\
\text { Interest based } \\
\text { Transaction }\end{array}$} & $f$ & 3 & 7 & 2 & 12 & 6 & 30 & \multirow{2}{*}{2.63} & \multirow{2}{*}{1.33} \\
\hline & $\%$ & 10 & 23.3 & 6.7 & 40 & 20 & 100 & & \\
\hline \multirow{2}{*}{$\begin{array}{c}\text { Maintain } \\
\text { accounts with } \\
\text { conventional } \\
\text { banks for your } \\
\text { deposits } \\
\end{array}$} & $f$ & 3 & 5 & 4 & 13 & 5 & 30 & \multirow[b]{2}{*}{2.60} & \multirow[b]{2}{*}{1.25} \\
\hline & $\%$ & 10 & 16.7 & 13.3 & 43.3 & 16.7 & 100 & & \\
\hline \multirow{2}{*}{$\begin{array}{c}\text { Your } \\
\text { organization } \\
\text { may play } \\
\text { significant role } \\
\text { in establishing } \\
\text { Islamic state }\end{array}$} & $f$ & 18 & 10 & 1 & 0 & 1 & 30 & \multirow[b]{2}{*}{4.47} & \multirow[b]{2}{*}{0.86} \\
\hline & $\%$ & 60 & 33.3 & 3.3 & 0 & 3.3 & 100 & & \\
\hline \multirow{2}{*}{$\begin{array}{l}\text { CSR can } \\
\text { contribute in } \\
\text { Da'wah }\end{array}$} & $f$ & 11 & 14 & 4 & 1 & 0 & 30 & \multirow[b]{2}{*}{4.17} & \multirow[b]{2}{*}{0.79} \\
\hline & $\%$ & 36.7 & 46.7 & 13.3 & 3.3 & 0 & 100 & & \\
\hline \multirow{2}{*}{$\begin{array}{c}\text { Your } \\
\text { employees are } \\
\text { Islamically } \\
\text { committed } \\
\end{array}$} & $f$ & 11 & 14 & 5 & 0 & 0 & 30 & \multirow[b]{2}{*}{4.20} & \multirow[b]{2}{*}{0.71} \\
\hline & $\%$ & 36.7 & 46.7 & 16.7 & 0 & 0 & 100 & & \\
\hline \multirow[b]{2}{*}{$\begin{array}{l}\text { During } \\
\text { recruitment, } \\
\text { your } \\
\text { organization } \\
\text { gives the } \\
\text { priority to the } \\
\text { applicant who } \\
\text { have Islamic } \\
\text { Background/co } \\
\text { mmitment }\end{array}$} & $f$ & 6 & 14 & 6 & 4 & 0 & 30 & \multirow[b]{2}{*}{3.73} & \multirow[b]{2}{*}{0.94} \\
\hline & $\%$ & 20 & 46.7 & 20 & 13.3 & 0 & 100 & & \\
\hline \multirow{2}{*}{$\begin{array}{c}\text { Your } \\
\text { organization } \\
\text { has significant } \\
\text { contribution in }\end{array}$} & $f$ & 13 & 17 & 0 & 0 & 0 & 30 & \multirow[b]{2}{*}{4.43} & \multirow[b]{2}{*}{0.50} \\
\hline & $\%$ & 43.3 & 56.7 & 0 & 0 & 0 & 100 & & \\
\hline
\end{tabular}


Practices of Corporate Social Responsibility: A Study on some Islamic Organizations in Bangladesh

\begin{tabular}{|c|c|c|c|c|c|c|c|c|c|}
\hline $\begin{array}{c}\text { the social } \\
\text { development }\end{array}$ & & & & & & & & & \\
\hline \multirow{2}{*}{$\begin{array}{c}\text { You have a } \\
\text { formal body } \\
\text { which is fully } \\
\text { concerned for } \\
\text { CSR }\end{array}$} & $f$ & 12 & 12 & 3 & 0 & 3 & 30 & \multirow[b]{2}{*}{4.00} & \multirow[b]{2}{*}{1.20} \\
\hline & $\%$ & 40 & 40 & 10 & 0 & 10 & 100 & & \\
\hline \multirow{2}{*}{$\begin{array}{c}\text { Your } \\
\text { organization } \\
\text { gives emphasis } \\
\text { on the } \\
\text { employees } \\
\text { welfare } \\
\end{array}$} & $f$ & 9 & 15 & 5 & 0 & 1 & 30 & \multirow[b]{2}{*}{4.03} & \multirow[b]{2}{*}{0.89} \\
\hline & $\%$ & 30 & 50 & 16.7 & 0 & 3.3 & 100 & & \\
\hline \multirow{2}{*}{$\begin{array}{c}\text { Your } \\
\text { organization } \\
\text { has a separate } \\
\text { budget for } \\
\text { CSR }\end{array}$} & $f$ & 8 & 17 & 1 & 2 & 2 & 30 & \multirow[b]{2}{*}{3.90} & \multirow[b]{2}{*}{1.09} \\
\hline & $\%$ & 26.7 & 56.7 & 3.3 & 6.7 & 6.7 & 100 & & \\
\hline \multirow{2}{*}{$\begin{array}{c}\text { Your } \\
\text { organization } \\
\text { contributes for } \\
\text { the Natural } \\
\text { Disasters } \\
\text { victims } \\
\end{array}$} & $f$ & 13 & 17 & 0 & 0 & 0 & 30 & \multirow[b]{2}{*}{4.43} & \multirow[b]{2}{*}{0.50} \\
\hline & $\%$ & 43.3 & 56.7 & 0 & 0 & 0 & 100 & & \\
\hline \multirow{2}{*}{$\begin{array}{c}\text { Your } \\
\text { organization } \\
\text { contributes for } \\
\text { the education }\end{array}$} & $f$ & 10 & 15 & 1 & 4 & 0 & 30 & \multirow[b]{2}{*}{4.03} & \multirow[b]{2}{*}{0.96} \\
\hline & $\%$ & 33.3 & 50 & 3.3 & 13.3 & 0 & 100 & & \\
\hline \multirow{2}{*}{$\begin{array}{l}\text { Your } \\
\text { Organization } \\
\text { donates in the } \\
\text { Health sector }\end{array}$} & $f$ & 6 & 14 & 2 & 8 & 0 & 30 & \multirow[b]{2}{*}{3.60} & \multirow[b]{2}{*}{1.10} \\
\hline & $\%$ & 20 & 46.7 & 6.7 & 26.7 & 0 & 100 & & \\
\hline \multirow{2}{*}{$\begin{array}{c}\text { Your } \\
\text { organization } \\
\text { contributes for } \\
\text { the Tree } \\
\text { plantation }\end{array}$} & $f$ & 4 & 10 & 9 & 7 & 0 & 30 & \multirow[b]{2}{*}{3.37} & \multirow[b]{2}{*}{1.00} \\
\hline & $\%$ & 13.3 & 33.3 & 30 & 23.3 & 0 & 100 & & \\
\hline \multirow{2}{*}{$\begin{array}{c}\text { Your } \\
\text { organization } \\
\text { contributes for } \\
\text { the Traffic } \\
\text { reduction }\end{array}$} & $f$ & 1 & 4 & 11 & 14 & 0 & 30 & \multirow[b]{2}{*}{2.73} & \multirow[b]{2}{*}{0.83} \\
\hline & $\%$ & 3.3 & 13.3 & 36.7 & 46.7 & 0 & 100 & & \\
\hline \multirow{2}{*}{$\begin{array}{l}\text { You perform } \\
\text { CSR with } \\
\text { Business }\end{array}$} & $f$ & 1 & 12 & 2 & 12 & 3 & 30 & \multirow{2}{*}{2.87} & \multirow{2}{*}{1.17} \\
\hline & $\%$ & 3.3 & 40 & 6.7 & 40 & 10 & 100 & & \\
\hline
\end{tabular}


IIUC Studies, Vol. 7

\begin{tabular}{|c|c|c|c|c|c|c|c|c|c|}
\hline Motive & & & & & & & & & \\
\hline \multirow{2}{*}{$\begin{array}{c}\text { CSR with } \\
\text { business } \\
\text { motive is not } \\
\text { harmful }\end{array}$} & $f$ & 5 & 12 & 4 & 8 & 1 & 30 & \multirow[b]{2}{*}{3.40} & \multirow[b]{2}{*}{1.16} \\
\hline & $\%$ & 16.7 & 40 & 13.3 & 26.7 & 3.3 & 100 & & \\
\hline \multirow[b]{2}{*}{$\begin{array}{l}\text { Government } \\
\text { should } \\
\text { encourage } \\
\text { companies to } \\
\text { be more } \\
\text { concerned for } \\
\text { CSR }\end{array}$} & $f$ & 12 & 18 & 0 & 0 & 0 & 30 & \multirow[b]{2}{*}{4.40} & \multirow[b]{2}{*}{0.50} \\
\hline & $\%$ & 40 & 60 & 0 & 0 & 0 & 100 & & \\
\hline \multirow{2}{*}{$\begin{array}{c}\text { CSR is related } \\
\text { with corporate } \\
\text { governance }\end{array}$} & $f$ & 10 & 19 & 1 & 0 & 0 & 30 & \multirow{2}{*}{4.30} & \multirow{2}{*}{0.54} \\
\hline & $\%$ & 33.3 & 63.3 & 3.3 & 0 & 0 & 100 & & \\
\hline \multirow[b]{2}{*}{$\begin{array}{c}\text { Islamic } \\
\text { Organizations } \\
\text { should have a } \\
\text { syndicate to } \\
\text { promote CSR } \\
\text { for the greatest } \\
\text { common } \\
\text { advantage in } \\
\text { the state. }\end{array}$} & $f$ & 12 & 12 & 3 & 3 & 0 & 30 & \multirow[b]{2}{*}{4.10} & \multirow[b]{2}{*}{0.96} \\
\hline & $\%$ & 40 & 40 & 10 & 10 & 0 & 100 & & \\
\hline Average Freq & & 8.4 & 12.9 & 3.2 & 4.4 & 1.1 & & 6.00 & 4.68 \\
\hline $\begin{array}{c}\text { Average } \\
\text { Percentage }\end{array}$ & & $\begin{array}{c}27.9 \\
9 \\
\end{array}$ & 43 & $\begin{array}{c}10.6 \\
6 \\
\end{array}$ & $\begin{array}{c}14.6 \\
6\end{array}$ & 3.66 & & $\begin{array}{c}19.9 \\
9 \\
\end{array}$ & $\begin{array}{c}15.6 \\
2\end{array}$ \\
\hline
\end{tabular}

(Source: Primary Data (Questionnaire has been given in the appendix)) 


\section{Questionnaire:}

The Practice of Corporate Social Responsibility: A Study on Some Islamic Organizations in Bangladesh

Alhamdulillah the authors are conducting a research on the above topic which will contribute to the knowledge of CSR in the said field. Could you please assist us giving the required information regarding your CSR practice? Your answers will be kept completely confidential and will only be used for academic purpose. Thanks for your cooperation.

Name of the Respondent:

Organization:

Designation:.

Gender: Male Female

How long have you been serving this organization?

Your Latest Degree:.

Result:......................

Please put Tick one cell for each of the statements:

\begin{tabular}{|l|l|l|l|l|l|}
\hline Questions & $\begin{array}{c}\text { Strongly } \\
\text { agree }\end{array}$ & Agree & Neutral & Disagree & $\begin{array}{l}\text { Strongly } \\
\text { disagree }\end{array}$ \\
\hline $\begin{array}{l}\text { 1. You believe in Interest } \\
\text { based Transaction }\end{array}$ & & & & & \\
\hline $\begin{array}{l}\text { 2. Maintain accounts with } \\
\text { conventional banks for your } \\
\text { deposits }\end{array}$ & & & & \\
\hline $\begin{array}{l}\text { 3. Your organization may } \\
\text { play significant role in } \\
\text { establishing Islamic state }\end{array}$ & & & & \\
\hline $\begin{array}{l}\text { 4. CSR can contribute in } \\
\text { Dawah }\end{array}$ & & & & \\
\hline $\begin{array}{l}\text { 5. Your employees are } \\
\text { Islamically committed }\end{array}$ & & & & \\
\hline $\begin{array}{l}\text { 6. During recruitment, your } \\
\text { organization gives the } \\
\text { priority to the applicant t } \\
\text { who have Islamic }\end{array}$ & & & & & \\
\hline
\end{tabular}


IIUC Studies, Vol. 7

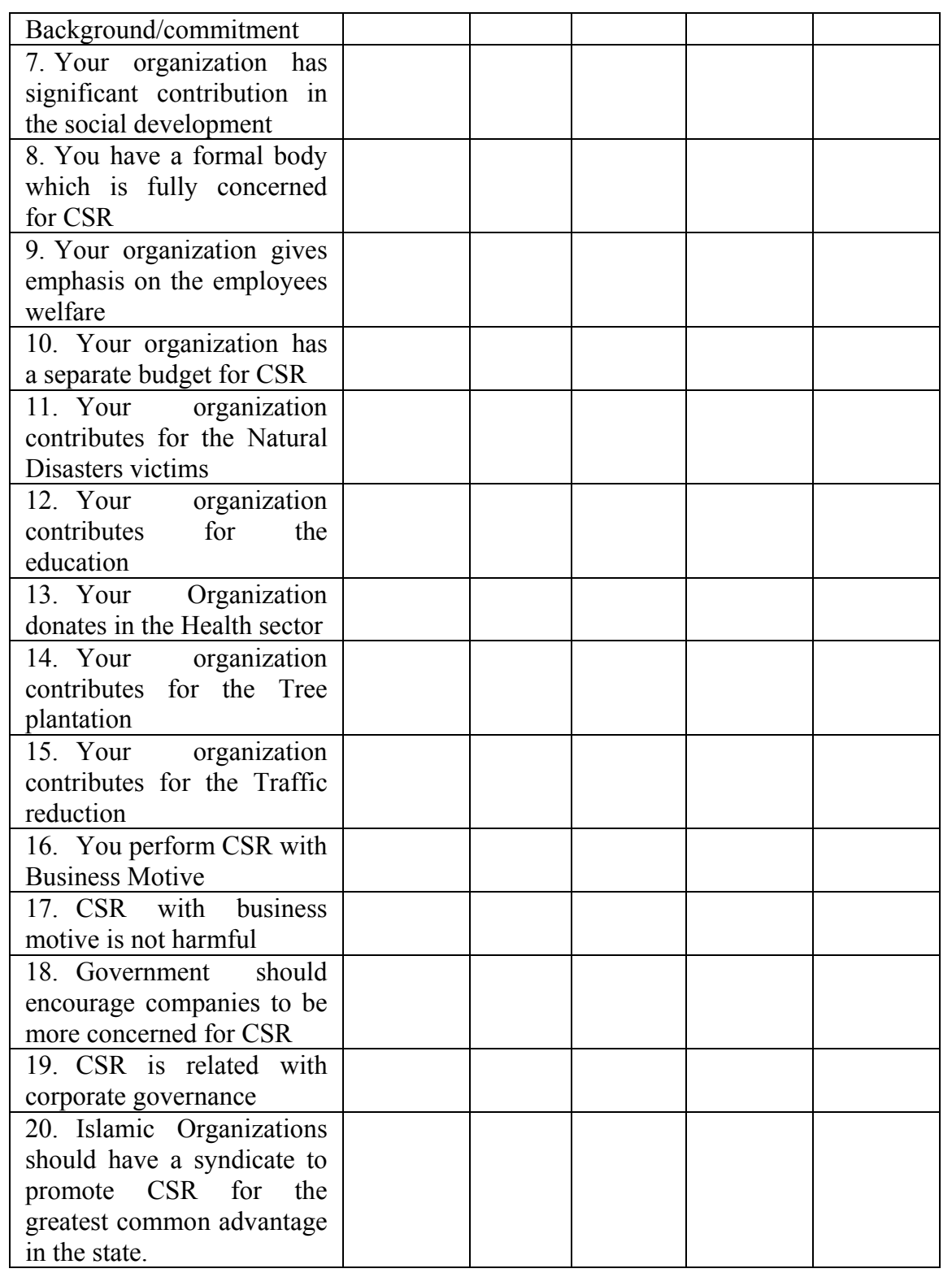

If you have any other formats of CSR you perform, please mention; 